\title{
Keynes and Wall Street
}

\section{David Chambers and Ali Kabiri}

\section{March 2016}

\begin{abstract}
This article examines in detail how John Maynard Keynes approached investing in the US stock market on behalf of his Cambridge College after the 1929 Crash. We exploit the considerable archival material documenting his portfolio holdings, his correspondence with investment advisors and his two visits to the US in the 1930s. Whilst he followed his enthusiasm for common stocks, he was equally attracted to investing in preferred stocks. His US stock picks reflected his detailed analysis of company fundamentals and a pronounced value approach. Already in this period, therefore, it is possible to see the origins of some of the investment techniques adopted by professional investors in the latter half of the twentieth century.
\end{abstract}


In 1925, when reviewing the study by E.L. Smith (1925), Keynes revealed his attraction to common stock investing. He challenged the conventional view that such stocks were too risky for general investors and wrote:

"The results are striking, Mr. Smith finds in almost every case, not only when prices are rising, but also when they were falling, that common stocks have turned out best in the long run.... This actual experience in the United States over the past fifty years affords prima facie evidence that the prejudice of investors and investing institutions in favour of bonds as being 'safe' and against common stocks as having, even the best of them, a 'speculative' flavor, has led to a relative overvaluation of bonds and undervaluation of common stocks."

The Smith study, entitled "Common Stocks as Long Term Investments", provided the first quantitative evidence on the extra return to be gained from a diversified portfolio of common stocks compared to that on a portfolio of corporate bonds over the period 1866-1922. At the time, institutional investor portfolios such as those of US university endowments were dominated by bonds, mortgages and real estate and had a very low weighting in common stocks (Goetzmann et al., 2010). Today, in contrast, such investors characterized by a long-term investment horizon have a strong bias towards equity and equity-like investments (Swensen, 2009).

Prior research has shown that Keynes was an innovative investor. He was among the first to exploit the newly emerged forward exchange market when speculating in currencies for himself (Accominotti and Chambers, 2015). At King's College, Cambridge, he made a substantial allocation to UK ordinary shares for the endowment, whilst other Oxbridge colleges stuck with bonds and property (Chambers and Dimson, 2013, Chambers Dimson and Foo, 2015). The subject of this article is to examine how he approached investing on Wall Street. To what extent did Keynes follow his own advice and invest in US common stocks? From where did his investment ideas spring? And how did he navigate his way through the troubled waters of Wall Street after 1929 ?

\footnotetext{
${ }^{1}$ JM Keynes “ An American Study of Shares versus Bonds as permanent investments" The Nation and The Athenaeum May 2, 1925 p157
} 
We address these questions by exploiting the complete record of the transactions Keynes undertook when running the endowment of King's College, Cambridge. He also traded US stocks for his personal portfolio. ${ }^{2}$ However, these records are not as easily understood as those of his college where he reported regularly on the endowment to the investment committee and the fellowship of King's. Nonetheless, a comparison of the US stocks in his personal portfolio with those of King's suggests that the two were run on similar lines and in large part held the same stocks. It is also worth stressing that Keynes appeared to take as much care with King's money as he did with his own.

His first foray into US common stocks for King's was in April 1929, when he purchased 100 shares of Massey Harris at \$51 only to sell them at a small loss in August. Whilst he made further purchases immediately after the crash in October, he soon sold in the months that followed suffering modest losses. He did not return in earnest to investing on Wall Street until 1931-32 and then continued his buying until the end of 1937. Stock lists, transaction sheets, correspondence and research reports from stockbrokers as well as archival material documenting his US visits allow us to document the evolution of his US investment portfolio.

The findings of our study are threefold. First, notwithstanding the attractions of common stock investing, Keynes invested as much in preferred as he did in common stocks. Wall Street in the 1920s and 1930s offered a degree of investment choice we do not see today. In the second half of the twentieth century, preferred stocks have largely disappeared both from investor portfolios and corporate balance sheets. Second, Keynes placed great store in fundamental security analysis. He was an enthusiastic consumer of stock research and undertook meetings with policy-makers and the company managements of his stocks. As with his UK stocks, his US stock portfolio displayed some pronounced tilts and did not merely mimic the market. Hence, the core of his portfolio focused on Investment Trusts, Industrials and Public Utilities, and he largely avoided Banking and Finance and Railroads. Last, Keynes employed a value approach to investing in US stocks. Of course, Keynes was not alone in pursuing such

\footnotetext{
${ }^{2}$ Keynes gained a little experience trading US stocks for his own account prior to the 1930s. In 1911, US Steel common stock became his first US investment and he traded this actively for several years after that. In 1926-27 he invested in Kennecott Copper but this was his only US holding in a portfolio of twenty stocks with a weighting of around $4 \%$.
} 
an approach. Most celebrated among his peers is Benjamin Graham, investor, Columbia Business School finance academic and author of the canonical "Security Analysis" (1934) and of a series of articles entitled "Is American Business Worth More Dead Than Alive?" published in 1932 by Forbes magazine. In the latter, Graham set out his thoughts on why the stock market values of many US corporations had fallen well below their liquidation values by 1932. Although the two men corresponded towards the end of Keynes' life on currency issues, to the best of our knowledge, Keynes developed his investment philosophy without seemingly being aware of the approach of this fellow value investor.

Much has been written about the 1929 Wall Street Crash and its aftermath. ${ }^{3}$ The prior literature tends to look at the aggregate market behavior swept along by successive waves of extreme optimism and then pessimism. In contrast, there have been few detailed studies of how investors behaved during this period of market turbulence. One important contribution of this article therefore is to start to fill this gap. In the process of doing so, we are able to detect the origins of some of the investment techniques adopted by institutional investors in the latter half of the twentieth century fundamental security analysis and investor meetings with company management, economists and policy-makers.

A second important contribution of this study is to make the connection between Keynes' activities as an investor and his economic writings. Chapter 12 of The General Theory (Keynes, 1936) sets out Keynes' views on the relationship between the stock market and the macro-economy. In many ways, this is an early treatise on behavioural finance. Here, the reader will find the "beauty contest" analogy explaining the mass psychology of the market; as well as the often-quoted sentence: "Worldly wisdom teaches us that it is better for reputation to fail conventionally than to succeed unconventionally." Both passages highlight the tendency to herding that can occur in stock markets, then and now, among individual and institutional investors alike. Such irrational behaviour can frustrate the more considered approach of the "long-term investor" looking to investment fundamentals for guidance in his stock selection. It is in this same chapter that we also encounter his reference to the concept of "animal

\footnotetext{
${ }^{3}$ Klein (2001) offers a good summary of this extensive literature.
} 
spirits" and to its influence on the decision-making of firms and investors. These are important observations which continue to inspire behavioral economists today (Akerlof and Shiller, 2009).

\section{The evolution of Keynes' US investments}

Keynes wore many investment hats. As well as investing his own money and that of his family and friends, Keynes also advised his college, two insurance companies, Eton School, and a London-listed closed end fund among others. Having become a fellow of King's in 1909, he subsequently became first bursar in 1921 and managed the college endowment fund continuously until his death in 1946. This role was closest to his heart and he used it to make substantial investments in the US during the 1930s.

King's was one of eighteen Cambridge colleges with their own endowments at this time and the third wealthiest. The University had its own endowment and Keynes played no formal role in managing these assets. The annual investment reports of the King's College endowment, written by Keynes for the college fellowship, together with year-end lists of security holdings and transactions sheets, are kept in the King's College Archives. Like many of the older Oxbridge colleges, King's had been a large real estate owner since its foundation and this asset class still dominated the endowment when Keynes took charge. As bursar, Keynes reported on the securities in the portfolio separately from the real estate holdings and in considerably more detail. Real estate valuations based on market prices were not undertaken during his time. Consequently, we are only able to estimate a market value with any degree of accuracy for the securities in the endowment. The value of all securities held by the College endowment grew from GBP 285,000 in August 1921 to GBP 1,252,000 in August 1946 at market prices (unadjusted for inflation) through a combination of investment performance and cash inflows. ${ }^{4}$

Within the overall security portfolio, Keynes managed the so-called "Discretionary Portfolio". It is this fund which he deemed was free from the restrictions of the UK's

\footnotetext{
${ }^{4}$ The first market valuations of property were not carried out until the early 1960s. Based on a very rough guess of its market value in 1919, real estate accounted for approximately $80 \%$ of the King's endowment when Keynes took up the reins. By 1946, this allocation had dropped to around 50\% through both Keynes' policy of property disposals and the strong performance of the stock-laden Discretionary Fund. See Chambers Dimson and Foo (2014)
} 
Trustee Acts and where he had full discretion to invest heavily in UK equities beginning in the 1920s (Chambers, Dimson and Foo, 2015). The benefit of this decision is illustrated by the superior performance of the Discretionary Portfolio with its heavy allocation to stocks in comparison with the Restricted Portfolio limited to fixed income investments (Chambers Dimson and Foo, 2013). Over the twenty-five years during which Keynes was responsible for the endowment the average annual total returns on the Discretionary Fund, the Restricted Fund, the UK stock market and the UK government bonds were $16.0 \%, 6.8 \%, 10.4 \%$ and, $7.1 \%$ respectively.

Keynes' allocation to US stocks within the Discretionary Fund averaged 33\% through the 1930s reaching a maximum of 50\% in 1939. Shortly thereafter, in January and April 1941, the UK Treasury requisitioned close to three-quarters of his US stocks by value in order to boost its US dollar reserves. Hence, Keynes made a substantial allocation to the US market within the Discretionary Fund and was rewarded with strong performance, albeit not quite as good as if he had left his portfolio invested entirely at home. The Fund's overall return was 16.5\% between September 1930 and August 1946, the period during which he invested in the US. Whilst his UK stocks performed about $1 \%$ better than this figure, his US stocks returned a little over $1 \%$ less than the overall fund return. Part of this difference was attributable to the depreciation in the US dollar against sterling over this period.

Having dipped a toe into the stock market in 1929, he withdrew it in the months that followed and only returned in 1932-33, buying in greater amounts in 1934, 1935 and 1936. Shiller (1981 p422, 2000 p 186) and Kabiri (2015 p 180-181) have furnished evidence suggesting that the market was considerably undervalued by the summer of 1932. Contemporary accounts such as those of Graham (1932) also reflected such beliefs. Keynes seems to have shared this opinion and, more importantly, acted on it.

\section{[Insert Figure 1 here]}

The detailed security transaction sheets enable us to trace Keynes' net purchases (sales) of US securities quarter by quarter on behalf of his college and compare them to the movements in the US stock market (Figure 1). The bars describe Keynes' quarterly net purchases and sales from 1929 to 1946. The line depicts the US market index described 
by the Cowles Index. ${ }^{5}$ The figure makes it apparent that Keynes began to invest when the market was at a low point in 1932-34. The sharp fall in Wall Street in 1937-38 appears to have caught him somewhat unawares. Despite some turnover of the portfolio, in the main, he stuck to his stock positions. In general, this pattern in his trading in the 1930s displays a tendency to a contrarian approach. Subsequently, the two occasions when he was forced to sell stock by the UK Treasury in 1941 visibly stand out. Thereafter, Keynes held his remaining investments and was largely inactive.

We valued all Keynes' US securities at market prices by sourcing common stock prices and dividends from the Center for Research in Security Prices (CRSP) and handcollecting preferred stock prices from the Commercial and Financial Chronicle. Dividends and arrears for preferred stocks were collected from Moody's Manual of Investments. All prices are end-of-month closing mid-market prices, and in the absence of a bid-ask quotations, the average of the daily high and low is taken.

\section{[Insert Table 1 here]}

Table 1 summarizes the total value of the US securities held by King's, the number of stocks held, and the percentage weighting by type of security and by sector for each financial year ended August, from 1930, the first year end for which US investments were reported, up to 1946, the year of Keynes death. His number of US security holdings peaked at 45 in August 1939 and the market value of his US holdings reached close to USD 800,000 in August 1936.

\section{Keynes' US Stock Picks}

What kind of stocks did Keynes favor? We first look at the types of securities and the sectors he invested in and then consider whether he preferred "value" or "growth" stocks and small or large capitalization stocks.

\footnotetext{
5 See Shiller's web site www.econ.yale.edu/ shiller/data/ie_data.xls. The Cowles Commission for research in Economics published a monograph in 1938 on indexes for US common stocks. The full series covers 1871-1937. Data from 1917 are taken from the "Standard Statistics weekly indices" and represent $90 \%$ of all common stocks listed on the NYSE. We use the P-1 series (ALL STOCKS). This valueweighted index has been used by Goetzmann and Ibbotson (2006). See Schwert (1990) for further discussion.
} 
Given his self-declared enthusiasm for common stocks, perhaps the most surprising finding in Table 1 is the fact that the average allocation to preferred stocks (44\%) was very similar to that of common stocks (42\%) across the whole period 1930-46. He began in 1935 to build large positions in Associated Dry Goods $2^{\text {nd }}$ preferred stock and subsequently in Chicago Pneumatic Tool 3\% cumulative convertible preferred stock. However, it was in the Public Utilities sector in particular that he favored preferred stocks including Electric Power and Light (EPL) 6\% preferred stock, EPL 7\% preferred stock and United Gas 7\% preferred stock. In so doing he avoided EPL common stock entirely and only purchased United Gas common stock in 1939.

Keynes' correspondence with his US advisers regarding these firms helps us understand why he believed that these preferred stocks were undervalued relative to their common stock counterparts. He surmised that the potential return to preferred stocks in the early 1930s was twofold - a potential income gain from the resumption of dividend payments and a capital gain from a narrowing in their discount to par value. Other things being equal, preferred stocks being without voting rights and without any claim to the residual cash flows of a firm tend to trade like bonds. Furthermore, preferred stock dividends are paid before common stock dividends and provide a more secure income stream in uncertain times. Normally, therefore, one would expect such preferred stocks to trade like bonds somewhere near their par value, typically $\$ 100$, in the absence of a sustained rise in the general level of interest rates. Yet, when Keynes initiated his positions in 1932-33, his preferred stocks traded on average at a 58\% discount to par value.

Such large discounts were explained by the difficulties firms had in paying preferred dividends in the aftermath of the 1929 Crash and with the onset of the Great Depression. The high level of corporate debt in real terms by the early 1930s (Kuvin, 1938) combined with declining corporate earnings meant that cash flows in many cases were insufficient to service preferred stock dividends which ranked below interest on debt. Consequently, concerns about the ability of firms to pay dividends weighed heavily on their preferred stock prices.

Keynes was attracted to those preferred stocks where dividends were in arrears. EPL $6 \%$, EPL $7 \%$ and United Gas $7 \%$ had arrears amounting to $\$ 17.50, \$ 20.50$ and $\$ 21.60$ 
per share respectively when Keynes began investing in a substantial way in $1935 .^{6}$ In the former two cases, these amounts were approximately equivalent to the then prevailing stock price. His belief was that the market would come to realize that these dividend arrears would at some stage be paid and as a result their depressed prices would rally. This was what subsequently happened. By 1936, the average discount on Keynes' preferred stocks had narrowed to $26 \%$ as their stock prices rallied back towards par.

Turning to the sector breakdown of his US investments, it is clear that Keynes concentrated his US portfolio on three sectors: Investment Trusts, Industrials and Public Utilities. ${ }^{7}$ His average weighting in these sectors was $29 \%, 27 \%$ and $21 \%$ respectively (Table 1). Unfortunately, a lack of data on sector weights for the US stock market in this period makes it difficult to know how Keynes' portfolio compared. However, the fact that King's had very little invested in two important sectors, Banking and Finance and Railroads, suggests that, in all likelihood, Keynes constructed a portfolio substantially different compared to the overall market.

There are two possible rationales for his favouring Investment Trusts. These trusts offer a diversified basket of stocks, which are likely to track a general recovery in the stock market. Hence, with stock prices at low levels in 1932, they would have offered one straightforward way for Keynes to bet on a market resurgence. Furthermore, investment trust stock prices can diverge from the underlying value of their investments which also trade on the market. In other words, they can trade at either a premium or a discount to their net asset value. Delong and Shleifer (1991) documented the existence of substantial premiums during the late 1920s, followed by substantial discounts in some cases in the early 1930s. Although some trusts traded at discounts from 1932 onwards, three of his investment trust core holdings - Tri-continental Common, General

\footnotetext{
${ }^{6}$ Keynes' investment in EPL 6\% preferred and EPL 7\% preferred from the early 1930s was also a "play" on United Gas. The two stocks were connected via a cross-holding resulting from a 1930 restructuring by which EPL acquired various securities of United Gas including virtually the entire $2^{\text {nd }}$ preferred stock issue. Keynes bought the United Gas $7 \% 1^{\text {st }}$ preferred, which ranked ahead of the $2^{\text {nd }}$ preferred in paying dividends. As the economic recovery continued and oil and gas prices rose from their trough in 1932 to a high in 1936, the probability of United Gas clearing the dividend arrears on its $1^{\text {st }}$ preferred stock and resuming payments on its $2^{\text {nd }}$ preferred stock increased accordingly. Since almost all of the latter issue was held by EPL, this in turn would assist the cash flows of EPL and the payment of the dividend arrears on the $6 \%$ and $7 \%$ preferred also held by Keynes. Hence, he was attracted to all three stocks.

${ }^{7}$ We follow the sector classification in Moody's Manuals.
} 
American Investors Common and Prudential Investors Common - appeared to trade at a premium to NAV at those times when Keynes was an active buyer. The net asset values attributable to common stock holders after deducting prior claims of these stocks had collapsed dramatically in the wake of the 1929 Crash and were zero or close to zero. As Shleifer and Delong (1991, p. 683) have argued the existence of such premiums to NAV was due to the severe effects of the leverage of Investment trusts on the collapsing value of their underlying investments. Seen in this way, an investor in their common stock could potentially realise large gains as these shares acted as long dated call options on the general stock market. Furthermore, it may indeed have been difficult in a very depressed market with low volumes to buy stocks held within the investment trust if Keynes had wanted to purchase these directly. Accordingly, selecting investment trusts may have been a more cost effective way to access the underlying stocks.

Keynes also had major holdings in the Industrials sector, for example, Homestake Mining. This gold mining investment averaged $10 \%$ of the total portfolio over the 8 years he held it from 1933. Homestake illustrates well how Keynes was willing to make large bets on special situations that were highly peculiar to the US depression economy. The attraction of this gold mining firm stemmed from the benefits accruing from the revaluation of gold from $\$ 20.67$ to $\$ 35$ per troy ounce by order of the US Government in March 1933, a move made to facilitate the recapitalisation of the US banking system (Friedman and Schwartz, 1963). His investment rationale was somewhat similar to that he employed when heavily overweighting South African gold mining shares in the 1930s in his UK portfolio on the back of the boost to revenues provided by the devaluation of the local currency since virtually all production was exported (Chambers and Dimson, 2013).

As we saw above when discussing preferred stocks, Keynes' other major sector bet was Public Utilities. He saw that this sector offered rich opportunities for those willing to go to the trouble of undertaking fundamental security analysis. Quite apart from the opportunity provided by preferred stock dividend arrears, there existed the potential from the substantial oil and gas deposits and undiscovered reserves held by some firms. In addition, there was considerable uncertainty surrounding the impact of regulatory intervention in the shape of the 1935 Public Utilities Holding Company Act (Wheeler- 
Rayburn Act) and, in particular, whether these companies might be broken up and reveal their intrinsic value. As mentioned above, in some cases, there were stock and bond cross-holdings among Public Utilities which added to the complexity of the analysis required to understand cash flows and security valuation.

In summary, Keynes' sector tilts in his US stock portfolio were considerable and his approach appears consistent with the one he took towards his UK stock portfolio. He largely avoided the same two sectors, Banks and Railroads, and had a substantial overweight allocation to the Mining sector compared to the market. It is also worth considering whether Keynes' US sector bets diversified his UK sector bets or not. Clearly, the absence of Banks and Railroads in both markets did not. Otherwise, the UK stock portfolio had very little if anything in Investment Trusts and Utilities in contrast to the US portfolio. Furthermore, he had only a comparatively modest investment in mining stocks despite Homestake and Climax Molybdenum being two of his core holdings. Whereas in the UK portfolio Keynes had a very substantial weighting in South African gold mines. The only real overlap was in Industrials. Here he did make direct comparisons regarding the valuation of Austin Motors, his largest UK holding, and General Motors where he had only modest positions. Using the valuation measure of market capitalization per automobile produced, he believed Austin was undervalued by as much as two-thirds compared to General Motors (King's Archives $\mathrm{JMK} / \mathrm{PC} / 1 / 221-2)$.

Overall, it seems reasonable to conclude that in terms of sector exposures his US stocks diversified his UK stocks within the overall endowment to a large degree. In the remainder of this section, we examine other pronounced characteristics of Keynes' stock picks and whether he displayed a preference for large or small firms and for value or growth firms.

The fact that the median stock he held was below the market capitalization of the average firm in the CRSP database indicates a slight tendency towards buying smaller stocks. Equally, however, he clearly also held some large capitalization stocks at certain times as indicated by the fact that approximately half of his stocks were larger than the market average and the other half below for most of the 1930s. 
Both today and in the 1930s, we can assess the extent to an investor follows a "value" style by comparing the book-to-market ratio of his stocks with the same ratio for the overall US stock market. The book-to-market ratio for a stock is the ratio of its book value, or its asset value as reported in the balance sheet, to its common stock market capitalization. Hence, the higher is the book-to-market ratio the higher is the asset value of a firm compared to its common stock valuation. Correspondingly, the same ratio for the overall stock market is defined as the aggregate book value divided by the aggregate market capitalization for all listed common stocks. Based on all firms with listed common stocks included in the CRSP database, the market book-to-market ratio averaged $1.3 x$ over the period $1930-46 .^{8}$ The valuation of the stock market reached a low in 1932 with a ratio of $2.8 x$ and a high in 1936 with a ratio of $0.8 x$. For each stock Keynes held, we compute its book-to-market ratio relative to the ratio of the overall market at calendar year-end. A relative book-to-market ratio above (below) 100\% therefore implies that a stock has a book-to-market ratio larger (smaller) than the market and would be classified as "value" ("growth").

Figure 2 plots the relative book-to-market ratio for the 25th percentile, median, and 75th percentile of the US stocks in Keynes' portfolio. Overall, there is a pronounced tilt towards high book-to-market stocks. The only years in which the median book-tomarket ratio among his stocks is below the market average are 1932 and 1945. In the intervening years, the relative book-to-market ratio of the $25^{\text {th }}$ percentile stock is close to or above the $100 \%$ mark, implying that the majority of his stocks can be classified as value stocks. The evidence points towards Keynes adopting a pronounced value approach in selecting his US stocks, particularly in the mid-thirties when he appeared to seek out value stocks as the market recovery took hold, and again in 1940-2.

In summary, we can see that Keynes' US stock picks displayed distinct characteristics. He concentrated on three sectors of the market, on preferred stocks as much as common stocks and exhibited a value bias. The tilt of his portfolio towards value stocks is

\footnotetext{
${ }^{8}$ Data on book values are taken from French (2014) and on market capitalisation values from CRSP. Where data is missing we use the Moody's Manuals. We exclude Investment Trusts.
} 
consistent with the approach he took to investing in UK stocks (Chambers and Dimson, 2013). In contrast, there is no evidence of the tilt towards smaller capitalization stocks that was present in his UK stock portfolio.

\section{How did Keynes pick his US stocks?}

The considerable correspondence between Keynes and his stockbrokers and investment advisers allows us to examine how Keynes went about picking his US stocks. There were three principle channels through which Keynes gathered information on US stocks. He made extensive use of stockbroker research. This he supplemented with extensive field visits to the US on two occasions in 1931 and again in 1934. Last, he employed his network of personal contacts to supplement his knowledge of the Wall Street scene.

The overall impression left by a careful reading of Keynes' correspondence with all these investment advisors is that he used outside advice to supplement his own deliberations on stocks. Ultimately, he made his own investment decisions rather than following stockbroker recommendations. Keynes primarily relied on two stockbroking and investment advisory firms for sourcing research on and trading his US investments, Case Pomeroy, based in New York, and Buckmaster \& Moore, based in London. To a lesser extent, he also used two other New York firms, Lazard Freres and Seligman and Co., and another London stockbroker, Lawrence, Keen \& Gardner.

Keynes had a close relationship over many years with several partners at Buckmaster and Moore who handled the vast majority of his UK stockbroking requirements. Most of his US trades were also conducted through Buckmaster and Moore, who charged UK brokerage commission in addition to US commission and cabling expenses. ${ }^{9}$ The London stockbroker provided Keynes with longer research notes as well as two-page company reports. In some cases, they would source research notes from other US investment firms on Wall Street and pass them on to Keynes. Most often, the flow of research reports from Buckmaster and Moore appears to have been in response to an idea Keynes had on a particular stock or sector. One such example is Keynes's enquiry

\footnotetext{
$9 \mathrm{BM} / 3 / 162$
} 
regarding Railroad stocks in June 1938. Following a request from Keynes, Buckmaster and Moore sent a telegram to their US research contact as follows: ${ }^{10}$

"We (B\&M) familiar with position Baltimore and Ohio, but have client interested depressed railroad bonds as long term speculation stop please mail your opinion relative attractions Baltimore Ohio Nickel Plate Illinois Central Southern Pacific bonds current prices stop particularly interested outlook freight, financial position, extent maintenance expenditure whether bonds held banks and savings banks and other factors you consider relevant stop indicate issues you prefer and whether junior mortgage issues better unsecured loans".

Buckmaster and Moore provided Keynes with a four-page letter analyzing the various bonds and recommending ten railroad bonds on the basis of their high yields and their ability to cover debt interest comfortably. ${ }^{11}$ Keynes acted on this information and initiated core holdings in two stocks - Baltimore and Ohio and New York, Chicago and St Louis. Other examples of research provided by Buckmaster and Moore are detailed notes on the performance of investment trusts in 1938 and on Keynes' major core holdings, Electric Power and Light, United Gas, and Climax Molybdenum in 1939. ${ }^{12}$

Keynes was not satisfied in getting his information solely through a London based UK broker and also looked to investment advisory firms based in the US. Among them, Case-Pomeroy, a small Wall Street investment banking and stock-broking firm with extensive London contacts, stood pre-eminent. His primary personal contact at the firm was Walter Case. His relationship with Case developed over a decade until Case's death in 1938 and was a close and amicable one. ${ }^{13}$ His firm furnished Keynes with US macroeconomic and financial market views as well as specific investment recommendations. ${ }^{14}$ As a general rule, Case offered stock ideas in response to Keynes soliciting his opinions on specific stocks or sectors. ${ }^{15}$ There was in addition an informal reciprocal agreement whereby Keynes supplied Case with information on the monetary

\footnotetext{
${ }^{10} \mathrm{SE} / 2 / 7 / 83$

${ }^{11} \mathrm{SE} / 2 / 7 / 92$

${ }^{12} \mathrm{SE} / 2 / 7 / 167$

${ }^{13}$ Case travelled to England circa 1938 to discuss investments with Keynes, RFK/13/213-6.

${ }^{14} \mathrm{BM} / 3 / 157$

${ }^{15} \mathrm{BM} / 3 / 162$
} 
and economic developments in Europe. ${ }^{16} \mathrm{He}$ also relied on Case when vetting other investment professionals. Approached by Warren Persons of the Goldman Sachs Trading Corporation in December 1930 about becoming a member of an informationsharing network, Keynes consulted with Case and rejected the offer upon concluding that he did not fully trust the merits of the endeavour. ${ }^{17}$

Other than Walter Case, Keynes corresponded with Case Pomeroy's main analyst, David. S. Roswell. Keynes regarded him as "an expert in long-range studies of the value of securities and intrinsic values of firms". ${ }^{18}$ Their correspondence developed as Keynes moved towards investing in public utilities, a sector which Keynes believed required an experienced analyst capable of conducting detailed balance sheet analysis. Keynes asked him for advice on choosing between the common and preferred stock of the two public utility firms, United Gas and Electric Power and Light, which as discussed above became core holdings in his portfolio.

The esteem in which he held Roswell was acknowledged in 1939 when, following the death of Case the previous year, Keynes duly signed up as a paying client of his new advisory firm, Roswell and Company. He also recommended Roswell to Prudential Insurance, a British insurance company where Keynes advised on investments, extolling his ability in long range forecasting of stock values, especially in the Public Utilities sector. ${ }^{19}$ An example of the extensive analysis, which Roswell conducted for Keynes, is the North American Company. The 13-page long analysis of this large public utility holding company in 1938 involved a full assessment of the value underlying the common stock requiring a detailed understanding of a highly complex network of subsidiaries and cross holdings and their break-up. ${ }^{20}$ Keynes was persuaded by Roswell's analysis and this stock became a core holding in the King's portfolio.

In 1931 and again in 1934, Keynes undertook month-long fact-finding visits to the US. On his first visit in May and June, he was invited to speak at the "New School for Social Research" in New York by Professor Alvin Johnson. When corresponding with

\footnotetext{
${ }^{16}$ One such example is a letter to Case advising on UK exchange rate policy in 1933, BM/2/311.

${ }^{17} \mathrm{BM} / 2 / 57$

${ }^{18} \mathrm{BM} / 3 / 157$

${ }^{19} \mathrm{BM} / 3 / 157$

${ }^{20} \mathrm{BM} / 3 / 52$
} 
Johnson ahead of his trip, he stated that the reason for the visit was to "gather information and not impart it". ${ }^{21}$ In fact, both visits proved important in helping him formulate his investment strategy and contributed to his adding to his US stockholdings in the months that followed.

From archival records, we have documented the types of individuals with whom Keynes met. Table 2 provides the detail on the people Keynes met on both his trips with links to business, investment and economic policy-making. This analysis reveals a distinct change of emphasis in the people he met across the two visits. Among the 28 meetings on his first trip, 9 were with bankers, 6 with investment advisers and 5 with central bankers. He had only 3 meetings with industrialists, and one each with a government official and an economist. This preponderance of appointments with bankers and investment advisers in 1931 subsequently gave way to meetings with politicians and government officials in 1934. On this second trip, Keynes held 27 meetings and met with politicians, government officials and industrialists on 8, 6, and 3 occasions respectively. In contrast, he met investment advisers and bankers on only three occasions. Half of the politicians he met were members of the Banking and Currency Committee.

\section{[Insert Table 2 here]}

Such a contrast in his two visit schedules very likely reflected a shift in the type of investment-related information Keynes was looking for. In the summer of 1931, it is likely that his appetite for information on government policy and the nature and extent of any proposed intervention in the economy was much greater than three years later. By 1934, the economy, banking system and stock market had all begun to turn the corner. Accordingly, Keynes' need for information on specific industries and individual corporations was relatively greater.

His first trip left him initially in a somewhat pessimistic mood as to the prospects for the US economy, its banking system and the stock market. His views at the very end of this trip were neatly summarized in a letter he sent from Case Pomeroy's offices in New

\footnotetext{
${ }^{21} \mathrm{AV} / 1 / 36$
} 
York to Buckmaster and Moore on $22^{\text {nd }}$ June 1931. In the letter, he stated that he saw "nothing attractive in US common stocks" and foresaw no "real recovery" in the economy. ${ }^{22} \mathrm{He}$ went on to state his belief that $10 \%$ of the reserve system banks, measured by assets, were insolvent. His worries included the high levels of "till money", "(banks')...desire for liquidity", the pressuring of bank customers for loan repayments and the fear of bank runs even when a bank was solvent. The plight of the banks he blamed on their purchases of second grade corporate bonds, trading at steep but uncertain discounts to face value, as well as on their "inadequately secured" loans to farmers and to real estate firms.

Despite his initial pessimism, his improved knowledge of the US investment scene and the contacts gained were important in giving him the necessary confidence to think about buying US stocks at a later date. A key indication of such confidence is revealed in a letter dated August 1932 requesting data and advice from Case-Pomeroy on the prospects for recovery in the US automobile industry. ${ }^{23}$ In September 1932, Keynes sent another letter to Walter Case in which he details his thoughts on the market having reached a low point and the improved prospects for a recovery. ${ }^{24}$ Therein he reasoned that stocks and commodities had begun recovering from levels "that were too low even in relation to a slump" once they began to rise from the trough in June 1932. ${ }^{25} \mathrm{He}$ also expressed his belief that the USD 1 billion program of large-scale open market operations undertaken by the Federal Reserve in March 1932 had halted the financial crisis, and that industrial output would recover in due course as a result of government spending and other interventions in the economy. His letter closed with the memorable phrase: "I should be a bull, but a scared bull - firm, but funky" in reference to his decision to start buying around the market low in the summer of $1932 .^{26}$

Keynes was a net buyer of US stocks in four out of the five quarters following the quarter ended December 1931 (Figure 1). He diversified his earlier purchases of investment trust stocks by seeking out value opportunities in both the common and preferred stocks of Industrial firms. Keynes again increased his US stock exposure after

\footnotetext{
${ }^{22} \mathrm{AV} / 1 / 92$

${ }^{23} \mathrm{BM} / 2 / 246$

${ }^{24} \mathrm{BM} / 2 / 242-5$

${ }^{25} \mathrm{BM} / 2 / 242$

${ }^{26}$ The word "funky" in this context means that he was afraid and hence sweating.
} 
his second visit. Anticipating a continuing recovery, he immediately began investing large sums of money in such economically sensitive sectors as Public Utilities and, to a lesser extent, Industrials, a strategy he continued through to 1937.

In addition to stock research reports and investment meetings, Keynes had an extensive network of personal contacts at his disposal. Prior research has shown that Keynes made use of his connections in the mining industry in selecting his UK core holdings (Chambers and Dimson, 2013). How important were these contacts in his selection of US core holdings? We define a core holding as any security held for a period of at least 5 years with a weighting greater than $1 \%$ of the total value of his US stocks. On this definition, there were 20 core stocks held for an average of over 9 years and together accounted for an average of two-thirds of his US portfolio across the whole period 1931-46 peaking at 89\% in 1941 (Table 3). Next, we define a "connection" as a director or officer of an investee company with whom Keynes has direct contact. ${ }^{27}$ Having gathered data on directors' and officers' names from the Moody's Manuals in 1930, we then match these names to Keynes' list of contacts for which there is evidence from his correspondence of a meeting having taken place. The column headed "Contact" in Table 3 indicates whether or not Keynes had a connection at one of his US core holdings.

\section{[Insert Table 3 here]}

Among the 20 core holdings, Keynes had a connection at 11 of them. Looking at his three main investment trust holdings, Walter Case (Case Pomeroy) was on the board of Selected Industries. Frederick Strauss (Seligman and Co) was a director of TriContinental, and Walter Kahn and Frank Altschul (Lazard Frères) were both directors at General American Investors. Keynes met with all of them in 1931. Keynes also met with directors and officers of Electric Power and Light (Frederick Strauss and S.Z. Mitchell) on his two visits and they were also officers or directors of Commonwealth and Southern Corporation. Since United Gas was part owned by Electric Power and Light, the transfer of information about United Gas to directors at Electric Power and Light was highly likely.

\footnotetext{
${ }^{27}$ We also include directors of non-core holdings with whom Keynes was connected who were themselves connected to directors or officers of Keynes' core holdings.
} 
There is something of a pattern here. In the Investment Trust and Public Utility sectors his connections appear to have been important, whilst in Industrials, they were not. We can only speculate as to the reasons why this pattern exists. One possible explanation might lie in the relative complexity of analysing Public Utility stocks and Investment Trusts referred to above. The former had complicated holding structures and were subject to considerable regulatory uncertainty; and the key to understanding the latter was comprehending the underlying intrinsic asset values of their stock portfolios.

\section{How did Keynes' US stocks do?}

For each of the US investments held by Keynes at the start of the calendar, we estimate the buy-and-hold total return, capital appreciation (depreciation) plus the dividend yield, over the following year. We then compute the total return on his US portfolio in a given year by averaging the buy-and-hold return on each security according to its weighting by the market value at the start of the year as a proportion of the total US portfolio. Whilst this method ignores the precise dates when he bought and sold a stock within a given calendar year, it provides a reasonable approximation of his overall portfolio performance.

Keynes' buy-and-hold returns for each year ended December the period 1930-45 are summarized in Table 4. The total return including dividends on the US stock market is measured by the Cowles Index. Across the whole period, the average annual buy-andhold return on his US investments was $13.6 \%$ comfortably exceeding the average market return of $8.1 \%$ per annum. His US investments did better than the overall markets in the majority of the 16 years he ran the portfolio. Other than 1930-31 194142 when he had relatively little money staked, his main period of underperformance was in 1936-38 when Wall Street entered a second bear market.

\section{[Insert Table 4]}

The analysis in Table 4 allows us to examine the performance of his common versus preferred stocks and his core versus non-core holdings. The average annual return on 
his common stocks $(+21.0 \%)$ slightly exceeded that on his preferred stocks $(+17.8 \%)$. Second, his core holdings $(+18.4 \%)$ performed considerably better than his non-core holdings $(+7.3 \%)$. Here is further evidence of his stock picking skills in that those stocks in which Keynes invested the most were his best performers.

Giving some consideration to risk, it is true that Keynes constructed a US stock portfolio which was more risky than the market. We saw above that he completely excluded certain sectors from his portfolio and adopted a pronounced tilt towards value stocks. Hence, it is no surprise to find that the volatility of his annual total returns was $37.2 \%$ compared to $27.9 \%$ for the market. However, King's and Keynes were wellrewarded for taking this level of risk. The reward-to-risk ratio is measured by the excess return over the risk-free rate divided by the standard deviation of returns and is known as the Sharpe Ratio. A ratio of 0.36 on Keynes' US stock portfolio and one of 0.47 for his common stocks alone comfortably exceeded the 0.29 ratio for the market.

A final question that arises is how did Keynes' US investment record compare to the others. A partial picture of Ben Graham's performance has been uncovered. This fragmentary evidence suggests that Graham outperformed the market from 1925-35 recording a return of $+6 \%$ per annum versus $+3.8 \%$ for the Dow Jones Industrials index. 28 There is no data for the remaining years which overlapped with Keynes' management of the King's portfolio. Quite possibly there may have been any number of investment opportunities after the 1929 Crash for those investors with a strong nerve prepared to undertake detailed security analysis. However, at this point we do not know and the authors are not aware of any other study of the peformance of US investment funds in this same time period.

\section{Summary}

Keynes was but one investor among many trying to make sense of the turbulent market conditions on Wall Street in the late 1920s and 1930s. This study of Keynes' US

\footnotetext{
${ }^{28}$ Irving Kahn and Robert D. Milne "Ben Graham: The Father of Financial Analysis" The Financial Analysts Research Foundation: Occasional paper no. 5 (1977), p.42-46.
} 
investment experience is only possible because of the detailed and extensive archival evidence which he left behind. As a result we can see his every investment move. The picture, which emerges from our analysis of Keynes' investments in US stocks on behalf of his Cambridge college gives a much-needed glimpse into how portfolio investment was practised in the wake of the greatest US stock market crash of the twentieth century. More research by business historians is needed in order to discover what other investors were doing.

Despite the appeal of common stocks, he allocated almost as much money to preferred stocks. On the whole, these stocks did about as well as his common stocks and considerably better than the overall common stock index. Today, preferred stocks have disappeared from institutional portfolios, which are dominated by common stocks and bonds. Before the post-WW2 changes in taxation, which disadvantaged these stocks, they played an important role in investor portfolios and in corporate finance. The 1920s and 1930s therefore represented a period of transition on the road to the "cult of the equity" which prevailed in the decades towards the end of the twentieth century.

He concentrated his portfolio on three sectors, Investment Trusts, Public Utilities, and Industrials and virtually ignored others, including Banking. Moreover, he displayed a liking for value stocks. Despite, to the best of our knowledge, never having discussed this topic with each other, both Keynes and Graham alighted on the same recipe for long-term investment success. His tilt toward value stocks and pronounced sector bets in the US portfolio, are consistent with how he also invested in UK stocks.

We can see from how Keynes went about picking stocks some elements of the investment approach adopted by professional portfolio managers today. Keynes was an enthusiastic consumer of well-executed stockbroker research and sought out the best industry analysts he could find, Roswell at Case Pomeroy being a prime example. He was not generally interested in stockbroker recommendations on individual stock names but rather used their research capability to analyse the stocks and industries in which he was interested. Furthermore, he visited policy-makers and the management of some of his largest investments making key contacts, which enabled him subsequently to monitor his investments. Such company meetings with policy-makers and with management are, an important tool of modern-day portfolio managers. 
Last but not least, Keynes wrote authoritatively about the psychology of investors and the stock market in The General Theory (Keynes, 1936). The intriguing question concerns the process by which he came to acquire these insights. It would seem reasonable to conclude that they in part at least arose from his own investment experiences. In the 1930s, Keynes himself had become the "long-term investor" carefully sifting through the fundamentals and attempting to withstand the irrational behaviour of the herd. Our aim in this study together with the companion studies on his UK stock trading (Chambers and Dimson, 2013, and Chambers Dimson and Foo, 2015) is to make the important connection between his work as an economist and his experiences as an investor. 


\section{References}

Olivier Accominotti and David Chambers “If You're So Smart: John Maynard Keynes and Currency Speculation in the Interwar Years" (2016) Journal of Economic History (forthcoming).

David Chambers and Elroy Dimson, "Retrospectives: John Maynard Keynes, Investment Innovator," Journal of Economic Perspectives 27(3) (Summer 2013): 213-228.

David Chambers, Elroy Dimson and Justin Foo “Keynes, King's and Endowment Asset Management" in Brown J. and Hoxby C. (ed.s) How the Great Recession Affected Higher Education. National Bureau of Economic Research. Chicago University Press (2014) ch.4 pp.127-150.

David Chambers, Elroy Dimson and Justin Foo, "Keynes the Stock Market Investor: A Quantitative Approach,” Journal of Financial and Quantitative Analysis 50 (4) (August 2015): 843-868

Commercial and Financial Chronicle (New York, n.d.)

J. Bradford De Long and Andrei Shleifer, "The Stock Market Bubble of 1929:

Evidence from Closed-end Mutual Funds,” Journal of Economic History 51(3) (September 1991): 675-700.

Milton Friedman and Anna J. Schwartz, A Monetary History of the United States, 1867-1960 (Princeton, 1963).

William N. Goetzmann and Roger G. Ibbotson, The Equity Risk Premium (Oxford, 2006).

William N. Goetzmann, John Griswold and Yung-Fang (Ayung) Tseng, "Educational Endowments in Crises," Journal of Portfolio Management 36(4) (Summer 2010): 112-123.

Benjamin Graham, “Is American Business Worth More Dead than Alive?” Forbes (1932).

Benjamin Graham and D. Dodd, Security Analysis (New York, 1934).

Ali Kabiri, The Great Crash of 1929 (Basingstoke, 2014).

John Maynard Keynes, The General Theory of Employment, Interest and Money. (London: Macmillan, 1936).

Irving Kahn and Robert D. Milne "Ben Graham The Father of Financial Analysis" The Financial Analysts Research Foundation: Occasional paper no. 5 (1977) 
Maury Klein, “The Stock Market Crash of 1929: A Review Article” Business History Review 75 (Summer 2001) 325-351.

Leonard Kuvin, Private Long-term Debt and Interest in the United States (New York, 1938).

John Moody, Moody’s Manual of Investments, American and Foreign, Railroad Securities (New York, n.d).

John Moody, Moody's Manual of Investments, American and Foreign, Industrial Securities (New York, n.d.).

John Moody, Moody’s Manual of Investments American and Foreign, Public Utilities (New York, n.d.).

John Moody, Moody's Manual of Investments, Banks - Insurance CompaniesInvestment Trusts - Real Estate - Finance and Credit Companies (New York, n.d.).

William Schwert, “Indexes of U.S. Stock Prices from 1802 to 1987”Journal of Business, 63 (July 1990) 399-426.

Robert J. Shiller, "Do Stock Prices Move Too Much to be Justified by Subsequent Dividends" American Economic Review 72 (3) (June, 1981): 421-436.

Robert J. Shiller, Irrational Exuberance (Princeton, N.J., 2000).

Robert Skidelsky, John Maynard Keynes, 1883-1946: Economist, Philosopher, Statesman. (New York: Penguin Books, 2005).

Edgar L. Smith, Common Stocks as Long Term Investments (New York, 1924).

David F. Swensen, Pioneering Portfolio Management, 2nd ed. (New York, 2009). 


\section{Table 1: US Security Holdings held by King's College, Cambridge 1930-46}

No. of Holdings and Total Market Value are in respect of the US securities held by the college at each August financial year end. All percentage figures are based on the Total Market Value of US security holdings. Common and preferred stocks are classified into sectors according to Moody's. Manuals.

\begin{tabular}{|c|c|c|c|c|c|c|c|c|c|c|c|c|c|c|c|c|c|}
\hline & 1930 & 31 & 32 & 33 & 34 & 35 & 36 & 37 & 38 & 39 & 40 & 41 & 42 & 43 & 44 & 45 & 46 \\
\hline No of Holdings & 2 & 4 & 16 & 12 & 37 & 41 & 39 & 33 & 43 & 45 & 37 & 20 & 22 & 23 & 22 & 23 & 19 \\
\hline \multirow[t]{2}{*}{$\begin{array}{l}\text { Total Mkt Value } \\
\text { (USD'000) }\end{array}$} & 9.9 & 17.6 & 97.3 & 110.9 & 248.1 & 495.7 & 789.8 & 701.6 & 557.1 & 532.2 & 433.9 & 139.7 & 102.7 & 241.3 & 288.8 & 317.5 & 290.2 \\
\hline & $\%$ & $\%$ & $\%$ & $\%$ & $\%$ & $\%$ & $\%$ & $\%$ & $\%$ & $\%$ & $\%$ & $\%$ & $\%$ & $\%$ & $\%$ & $\%$ & $\%$ \\
\hline Common & 61.1 & 100.0 & 72.4 & 57.3 & 42.9 & 28.5 & 36.6 & 46.8 & 39.7 & 45.0 & 35.1 & 28.6 & 29.0 & 22.6 & 21.8 & 34.8 & 37.7 \\
\hline Preferred & 38.9 & 0.0 & 4.2 & 26.3 & 51.3 & 65.8 & 60.1 & 52.5 & 56.1 & 51.1 & 59.0 & 50.2 & 51.0 & 41.0 & 43.9 & 32.1 & 35.0 \\
\hline \multirow[t]{2}{*}{ Bonds } & 0.0 & 0.0 & 23.4 & 16.4 & 5.8 & 5.7 & 3.3 & 0.7 & 4.2 & 3.9 & 5.9 & 21.2 & 20.1 & 36.4 & 34.3 & 33.1 & 27.3 \\
\hline & 100.0 & 100.0 & 100.0 & 100.0 & 100.0 & 100.0 & 100.0 & 100.0 & 100.0 & 100.0 & 100.0 & 100.0 & 100.0 & 100.0 & 100.0 & 100.0 & 100.0 \\
\hline Banks \& Finance & 0.0 & 0.0 & 0.0 & 0.0 & 0.0 & 0.0 & 0.0 & 0.0 & 0.0 & 0.0 & 0.0 & 0.0 & 0.0 & 0.0 & 0.0 & 0.0 & 0.0 \\
\hline Investment Trusts & 0.0 & 100.0 & 50.5 & 30.0 & 26.0 & 26.4 & 25.3 & 21.7 & 20.4 & 19.8 & 22.7 & 23.2 & 24.9 & 20.1 & 23.9 & 27.9 & 35.4 \\
\hline Industrials & 38.9 & 0.0 & 8.1 & 46.7 & 42.3 & 38.7 & 24.0 & 29.0 & 30.2 & 32.5 & 24.0 & 30.1 & 34.1 & 17.8 & 16.7 & 24.3 & 21.8 \\
\hline Public Utilities & 0.0 & 0.0 & 14.3 & 5.8 & 22.9 & 27.5 & 44.3 & 41.6 & 37.3 & 34.3 & 41.6 & 15.5 & 15.3 & 18.6 & 18.8 & 7.7 & 7.0 \\
\hline Railroads & 61.1 & 0.0 & 11.1 & 2.5 & 7.2 & 6.6 & 6.0 & 1.2 & 4.4 & 5.0 & 6.0 & 20.6 & 23.9 & 12.6 & 12.6 & 13.4 & 11.0 \\
\hline \multirow[t]{2}{*}{ Bonds } & 0.0 & 0.0 & 16.0 & 15.1 & 1.5 & 0.7 & 0.4 & 0.5 & 0.6 & 0.3 & 0.4 & 0.6 & 0.0 & 26.3 & 23.8 & 22.4 & 19.3 \\
\hline & 100.0 & 100.0 & 100.0 & 100.0 & 100.0 & 100.0 & 100.0 & 100.0 & 100.0 & 100.0 & 100.0 & 100.0 & 100.0 & 100.0 & 100.0 & 100.0 & 100.0 \\
\hline
\end{tabular}

Source: King's College Archives and authors' own calculations 
Table 2: Keynes' Meetings on his trips to the US in 1931 and 1934

\section{Panel A: 1931 meetings}

\begin{tabular}{|c|c|}
\hline NAME & AFFILIATION \\
\hline \multicolumn{2}{|l|}{ Banker } \\
\hline Benjamin Anderson & Chase National Bank \\
\hline Melvin Traylor & First National Bank, Chicago \\
\hline George Davidson & President, Central Hanover Bank and Trust Co \\
\hline George M Reynolds & Continental Illinois Bank and Trust company \\
\hline Walter Lichtenstein & First National Bank of Chicago \\
\hline Jackson Reynolds & President, First National Bank \\
\hline Harold Stanley & JP Morgan \\
\hline Russell Leffingwell & JP Morgan \\
\hline Benjamin Anderson & Chase National Bank \\
\hline \multicolumn{2}{|l|}{ Investment Advisor } \\
\hline Albert Forsch & Lazard Frères \\
\hline Lester Perrin & Lazard Frères \\
\hline Walter Kahn & Economist of Lazard Frères \\
\hline Alexander Sachs & Lehman Corp \\
\hline Frederick Strauss & Seligman and Co \\
\hline Henry Breck & Seligman and Co \\
\hline \multicolumn{2}{|l|}{ Central Banker } \\
\hline Leon Fraser & Director, Bank for International Settlements \\
\hline W.R. Burgess & Deputy Governor, Federal Reserve Bank of New York \\
\hline Dr. E A Goldenweiser & Federal Reserve Board \\
\hline Dr. Adolf Miller & Federal Reserve Board \\
\hline Governor McDougal & Federal Reserve Bank of Chicago \\
\hline \multicolumn{2}{|l|}{ Industrialist } \\
\hline Dr H D Daikin & Chemist and Inventor \\
\hline Orlando Weber & President, Allied Chemical Corp \\
\hline Mr Owen D Young & Rockefeller Foundation/Radio Corp America \\
\hline \multicolumn{2}{|l|}{ Government Official } \\
\hline T.F.Woodlock & Former Interstate Commerce Commissioner \\
\hline \multicolumn{2}{|l|}{ Economist } \\
\hline L. Kuvin & National Industrial Conference Board \\
\hline \multicolumn{2}{|l|}{ Life Insurance Co. } \\
\hline David F Houston & President of the Mutual Life Insurance company \\
\hline \multicolumn{2}{|l|}{ Other } \\
\hline Paul Cravath & New York corporate lawyer \\
\hline Charles P Howland & Council on Foreign Relations; "Foreign Affairs" magazine \\
\hline
\end{tabular}




\section{Panel B: 1934 meetings}

\begin{tabular}{|c|c|}
\hline NAME & AFFILIATION \\
\hline \multicolumn{2}{|l|}{ Politician } \\
\hline Senator Duncan Fletcher & $\begin{array}{l}\text { (Democrat) Florida, Chairman banking and currency } \\
\text { committee }\end{array}$ \\
\hline Senator Frederic Collin Wolcott & $\begin{array}{l}\text { (Republican) Connecticut, Member banking and currency } \\
\text { and labour committees }\end{array}$ \\
\hline Senator Robert J Bulkley & $\begin{array}{l}\text { (Democrat) Ohio, Member banking and currency, joint } \\
\text { author of the Federal Reserve Act with Carter Glass }\end{array}$ \\
\hline Senator Alva B Adams & $\begin{array}{l}\text { (Democrat) Colorado, Member banking and currency, } \\
\text { mines and mining committees }\end{array}$ \\
\hline Senator Charles McNary & $\begin{array}{l}\text { (Republican) Oregon, Member commerce, agri. \& } \\
\text { forestry, manufactures, territories and insular affairs ctte. }\end{array}$ \\
\hline Senator John G Townsend & $\begin{array}{l}\text { (Republican) Delaware Member banking and currency, } \\
\text { appropriations committees }\end{array}$ \\
\hline Francis Sayre & Asst. Secretary of State, in charge of economics questions \\
\hline Ogden L Mills & Secretary of the Treasury (1933) \\
\hline \multicolumn{2}{|l|}{ Government Official } \\
\hline Herbert Feis & Economist for Dept. of State \\
\hline Louis Brandeis & US Supreme Court \\
\hline Joseph B Eastman & Interstate Commerce Commission \\
\hline Edward P Costigan & US Senate \\
\hline Rexford G Tugwell & Dept Agriculture \\
\hline Frances Perkins & Dept of Labour \\
\hline \multicolumn{2}{|l|}{ Industrialist } \\
\hline Alfred Sloan & General Motors \\
\hline Walter Chrysler & Chrysler Corp \\
\hline Whitney Shephardson & Council on Foreign Relations; United Fruit Co. \\
\hline \multicolumn{2}{|l|}{ Investment Advisor } \\
\hline Frank Altschul & Lazard Frères \\
\hline Walter Case & Case Pomeroy \\
\hline \multicolumn{2}{|l|}{ Academic } \\
\hline Dean W. B. Donham & Director: Harvard Graduate School of Business \\
\hline \multicolumn{2}{|l|}{ Economist } \\
\hline Dr Wesley C Mitchell & Director: National Bureau of Economic Research \\
\hline \multicolumn{2}{|l|}{ Banker } \\
\hline Russell Leffingwell & JP Morgan \\
\hline \multicolumn{2}{|l|}{ Other } \\
\hline Allen Dulles & Council on Foreign Relations (secretary) \\
\hline Walter Lipman & Jounalist \\
\hline Dr John H Williams & Council on Foreign Relations \\
\hline Hamilton Fish Armstrong & $\begin{array}{l}\text { Journalist "Foreign Affairs" magazine; Council on } \\
\text { Foreign Relations }\end{array}$ \\
\hline John Foster Dulles & Lawyer \\
\hline
\end{tabular}

Source: King’s College Archives 


\section{Table 3: US Core Holdings held by King's College, Cambridge 1931-45}

All figures are the percentage weighting of a security in the US portfolio valued at August year end. A core holding is defined as a security held for at least 5 years with a weighting in the total portfolio greater than $1 \%$. Contact refers to whether or not Keynes had a meeting with an officer or director of the company.

\begin{tabular}{|c|c|c|c|c|c|c|c|c|c|c|c|c|c|c|c|c|c|c|c|}
\hline SECURITY NAME & TYPE & CONTACT & AVE. & 1931 & 32 & 33 & 34 & 35 & 36 & 37 & 38 & 39 & 40 & 41 & 42 & 43 & 44 & 45 & 46 \\
\hline \multicolumn{20}{|l|}{ Investment Trusts } \\
\hline Atlas Corp & $\mathrm{Cmn}$ & $\mathrm{N}$ & 3.4 & & & & & 3.8 & 3.5 & 1.1 & 2.2 & 4.2 & 5.4 & & & & & & \\
\hline General American Investors Co. Inc. & $\mathrm{Cmn}$ & $\mathrm{Y}$ & 7.8 & 28.1 & 7.0 & & & 1.9 & 2.8 & & 4.4 & 5.2 & 5.2 & & & & & & \\
\hline Prudential Investors & $\mathrm{Cmn}$ & $\mathrm{N}$ & 1.8 & & 4.4 & & 1.2 & 0.9 & 2.5 & 3.1 & 2.2 & 2.0 & 3.2 & 0.6 & 0.0 & 0.1 & & & \\
\hline Selected Industries Inc. allot. Certs & $\mathrm{Cmn}$ & $\mathrm{Y}$ & 16.3 & 29.3 & 22.8 & 20.4 & 10.5 & 7.3 & 7.3 & & & & & & & & & & \\
\hline Tri Continental Common & $\mathrm{Cmn}$ & $\mathrm{Y}$ & 8.4 & 22.0 & 4.8 & 3.0 & 0.9 & 2.2 & 3.8 & 8.6 & 6.5 & 3.7 & 2.7 & 8.3 & 7.4 & 10.6 & 11.8 & 16.6 & 21.3 \\
\hline \multicolumn{20}{|l|}{ Industrials } \\
\hline Associated Dry Goods & 7\% 2nd Pref & $\mathrm{Y}$ & 3.8 & & & & & 3.5 & 2.9 & 3.0 & 2.6 & 2.1 & 1.5 & 7.5 & 6.3 & 3.6 & 3.4 & 3.8 & 4.7 \\
\hline Carriers \& General Corp & $\mathrm{Cmn}$ & $\mathrm{N}$ & 3.0 & & & & & & 0.9 & 1.9 & 1.3 & 1.1 & 1.2 & 4.4 & 4.7 & 3.6 & 3.6 & 4.2 & 5.9 \\
\hline Chicago Pneumatic Tool Co. & $3 \%$ conv Pref & $\mathrm{N}$ & 6.4 & & & & & & & 1.9 & 2.6 & 2.6 & 2.9 & 12.5 & 13.7 & 6.3 & 6.5 & 6.7 & 7.7 \\
\hline Climax Molybdenum Co. & $\mathrm{Cmn}$ & $\mathrm{N}$ & 3.3 & & & & & & & & & 1.5 & 1.3 & 6.2 & 7.5 & 3.2 & 2.3 & 2.4 & 2.0 \\
\hline Homestake Mining & $\mathrm{Cmn}$ & $\mathrm{N}$ & 10.5 & & & 33.8 & 19.5 & 11.5 & 8.2 & 8.2 & 1.0 & 1.0 & 0.7 & & & & & & \\
\hline \multicolumn{20}{|l|}{ Public Utilities } \\
\hline Commonwealth \& Southern Corp & $6 \%$ Pref & $\mathrm{Y}$ & 5.2 & & & 4.1 & 4.3 & 3.2 & 6.2 & 6.3 & 6.8 & 5.3 & 5.6 & & & & & & \\
\hline Electric Power \& Light Corp. & $7 \%$ Pref & $\mathrm{Y}$ & 9.2 & & & & & & 4.9 & 11.9 & 8.0 & 2.8 & 4.3 & 12.9 & 10.5 & 16.1 & 16.5 & 4.1 & \\
\hline Electric Power \& Light Corp. & $6 \%$ Pref & $\mathrm{Y}$ & 4.3 & & 4.2 & 1.7 & 0.3 & 4.3 & 9.2 & 8.1 & 4.7 & 2.5 & 3.9 & & & & & & \\
\hline United Corp. & $\mathrm{Cmn}$ & Y & 1.9 & & 1.3 & & & & 2.2 & 2.3 & 1.5 & 1.5 & 1.4 & 1.2 & 0.8 & 2.2 & 1.7 & 2.2 & 4.3 \\
\hline United Corp. & $3 \%$ Pref & $\mathrm{Y}$ & 2.4 & & & 2.9 & 1.0 & 0.8 & 0.6 & 2.2 & 3.4 & 3.5 & 5.0 & & & & & & \\
\hline United Gas Corp. & $7 \%$ Pref & $\mathrm{Y}$ & 11.9 & & & & 6.6 & 15.0 & 16.7 & & 6.8 & 11.9 & 14.7 & & & & & & \\
\hline \multicolumn{20}{|l|}{ Railroads } \\
\hline Baltimore \& Ohio RR & $5 \%$ 1st Bonds & $\mathrm{N}$ & 6.1 & & & & & & & & 1.6 & 2.3 & 3.2 & 10.5 & 11.1 & 6.2 & 6.3 & 6.5 & 7.0 \\
\hline New York Chicago \& St Louis RR & 4.5\% Ref'g C & $\mathrm{N}$ & 3.0 & & & & & & & & 0.6 & 0.9 & 1.3 & 4.7 & 6.2 & 3.3 & 3.4 & 3.2 & \\
\hline Stocks with a contact & & & 44.8 & 79.4 & 40.1 & 32.2 & 23.6 & 38.2 & 58.7 & 46.0 & 49.2 & 43.1 & 49.5 & 45.7 & 42.5 & 41.8 & 45.3 & 37.7 & 43.9 \\
\hline Stocks without a contact & & & 22.3 & 0.0 & 4.4 & 33.8 & 20.8 & 16.1 & 15.1 & 17.7 & 12.8 & 17.4 & 21.4 & 43.1 & 45.0 & 27.4 & 26.2 & 27.3 & 28.1 \\
\hline
\end{tabular}

Source: King's College Archives and authors' own calculations 

1930-45

All figures are value-weighted buy-and-hold total returns including dividends for each calendar year ended December. US Market refers to the total return on common stocks represented by the Cowles Index. Excess is the difference between the total portfolio and the US market returns, Core refers to core holdings defined as securities held for at least 5 years with a weighting in the total portfolio greater than $1 \%$. S.D. is standard deviation and S.R. is the Sharpe ratio, defined as the excess return on the total portfolio over the risk free rate divided by the standard deviation of returns.

\begin{tabular}{|c|c|c|c|c|c|c|c|c|}
\hline $\begin{array}{l}\% \\
\text { Dec }\end{array}$ & Total & US Market & Excess & Common & Preferred & Bonds & Core & Non Core \\
\hline 1930 & -37.1 & -23.0 & -14.1 & -36.2 & & & & \\
\hline 1931 & -51.0 & -39.8 & -11.2 & -51.0 & & & -50.0 & -52.1 \\
\hline 1932 & 28.7 & -11.5 & 40.2 & 43.7 & 0.0 & -46.5 & 44.6 & -3.9 \\
\hline 1933 & 70.4 & 53 & 17.4 & 102.1 & 3.2 & -14.8 & 8.7 & 105.0 \\
\hline 1934 & 26.2 & -2.7 & 28.9 & 23.7 & 26.9 & 114.2 & 28.6 & 23.9 \\
\hline 1935 & 56.3 & 45.7 & 10.6 & 57.4 & 61.1 & 2.8 & 74.3 & 45.0 \\
\hline 1936 & 32.9 & 35.2 & -2.3 & 18.8 & 40.6 & 32.8 & 46.9 & 13.9 \\
\hline 1937 & -40.9 & -30.8 & -10.1 & -40.2 & -42.5 & -13.6 & -38.4 & -47.0 \\
\hline 1938 & 17.1 & 21.5 & -4.4 & 22.2 & 12.7 & 3.2 & 13.7 & 20.7 \\
\hline 1939 & 5.7 & 1.8 & 3.9 & -6.7 & 14.7 & 7.0 & 7.6 & 2.7 \\
\hline 1940 & -0.9 & -9.6 & 8.7 & -9.8 & 5.9 & 5.8 & 0.5 & -3.5 \\
\hline 1941 & -24.1 & -10.2 & -13.9 & -11.0 & -36.1 & 14.8 & -15.7 & -43.4 \\
\hline 1942 & 3.1 & 16.1 & -13.0 & 54.7 & -2.9 & -31.1 & 7.6 & -32.9 \\
\hline 1943 & 65.3 & 26.8 & 38.5 & 51.9 & 85.4 & 36.8 & 68.4 & 46.5 \\
\hline 1944 & 31.1 & 19.6 & 11.5 & 34.6 & 42.4 & 15.9 & 37.0 & 17.7 \\
\hline 1945 & 35.0 & 37.3 & -2.3 & 81.1 & 37.7 & -0.4 & 42.3 & 16.3 \\
\hline Mean & 13.6 & 8.1 & 5.5 & 21.0 & 17.8 & 9.1 & 18.4 & 7.3 \\
\hline S.D. & 37.2 & 27.9 & 18.1 & 44.2 & 34.8 & 37.7 & 35.7 & 41.5 \\
\hline S.R. & 0.36 & 0.29 & 0.30 & 0.47 & 0.51 & 0.24 & 0.52 & 0.17 \\
\hline
\end{tabular}

Source: King's College Archive and authors' calculations 
Figure 1: Keynes Purchases and Sales of US securities held by King's 1929-46

The bars indicate the net purchases and sales at a quarterly frequency in USD '000s. (left hand scale). The shaded grey area (right hand scale) indicates the level of the overall US Stock market represented by the Cowles (1938) Index. King's College financial year end is August.

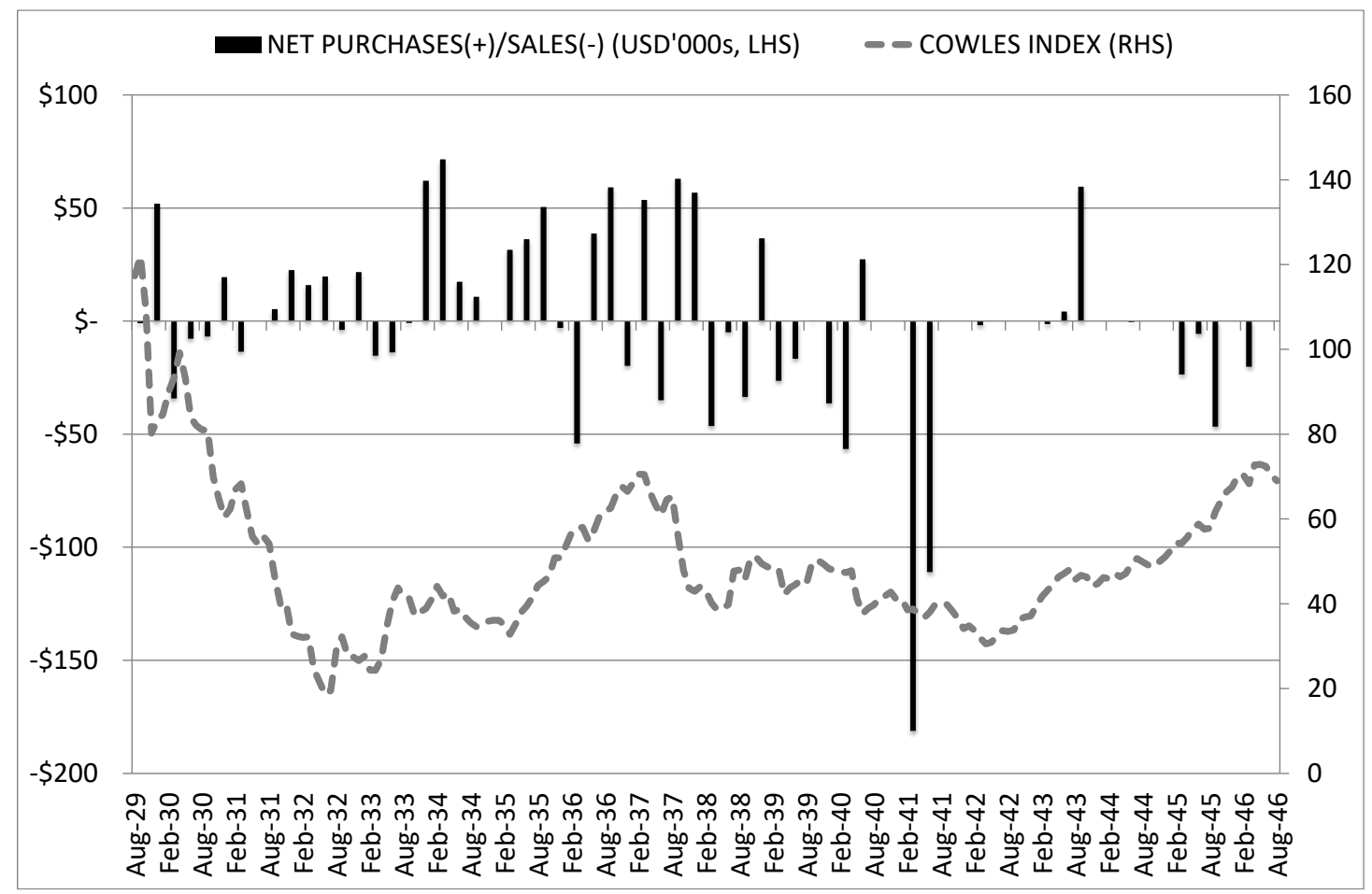


Figure 2: Relative Book-to-Market Ratio of US stocks held by King's 1932-45

We plot the distribution of relative book-to-market ratios of the stocks held by King's at each calendar year end, where relative book-to-market is the book-to-market ratio of each stock expressed as a percentage of the book-to-market ratio of the overall market as described by the CRSP universe of US stocks (French, 2014). The shaded grey area shows the distribution of the relative book-to-market ratios between the $25^{\text {th }}$ percentile (bottom) and $75^{\text {th }}$ percentile (top). The black line represents the median relative book-to-market ratio. Investment Trust holdings are excluded.

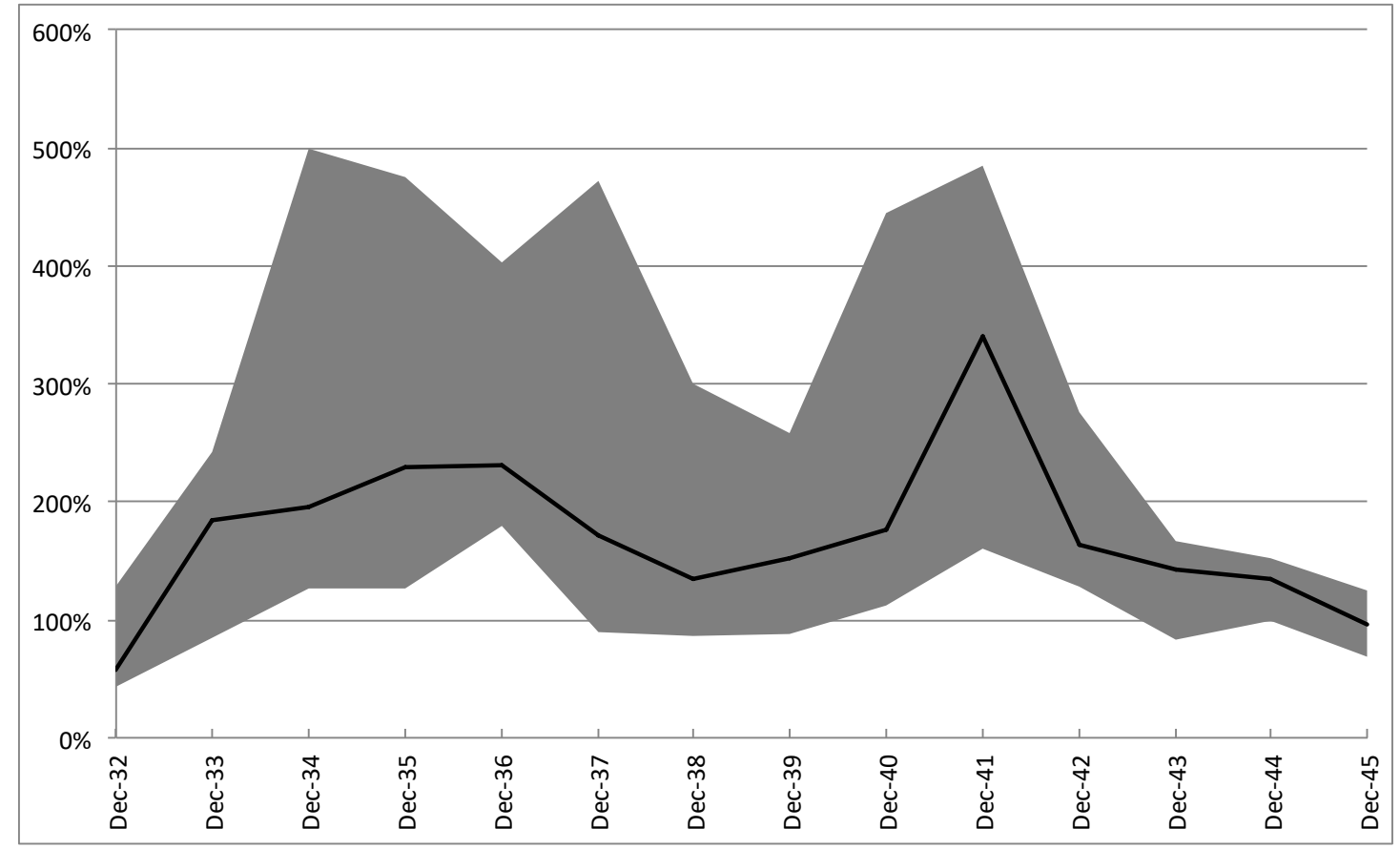

